DOI: https://doi.org/10.31539/jks.v1i2.80

\title{
PENGARUH PERMAINAN PUZZLE TERHADAP KEMAMPUAN BERADAPTASI SOSIAL SISWA RETARDASI MENTAL
}

\author{
Dwi Wulandari ${ }^{1}$, Nelvia $^{2}$, Dwi Saputra ${ }^{3}$ \\ Program Studi Ners, STIKES Dehasen Bengkulu ${ }^{1,2,3}$ \\ dwiwulandari3599@gmail.com ${ }^{1}$
}

\begin{abstract}
ABSTRAK
Tujuan penelitian ini untuk mengetahui pengaruh puzzle play terhadap adaptasi sosial pada siswa retardasi mental di dharma wanita SDLB Kota Bengkulu. Desain penelitian yang digunakan adalah pre exsperimental design dengan rancangan form satu kelompok pretest-posttest. Hasil penelitian menunjukkan bahwa rata-rata jumlah anak yang mengalami keterbelakangan mental sebelum permainan puzzle memiliki adaptasi sosial yang tidak menguntungkan dan rata-rata jumlah anak yang mengalami keterbelakangan mental setelah melakukan permainan puzzle memiliki adaptasi sosial yang cukup baik dan tidak ada efek antara bermain teka-teki. Untuk adaptasi sosial pada siswa dengan keterbelakangan mental pada Wanita Dharma SDLB dikota Bengkulu ( $\mathrm{p}=0,004)$. Simpulan, ada pengaruh antara bermain puzzle terhadap kemampuan beradaptasi sosial pada siswa retardasi mental di SDLB Dharma Wanita Kota Bengkulu.
\end{abstract}

Kata Kunci: Adaptasi Sosial, Permainan Puzzle, Retardasi Mental

\begin{abstract}
The purpose of this study was to determine the effect of puzzle play social adaptation on mental retardation students in SDLB Dharma Wanita Bengkulu City. The research design used was pre-experimental design with the design of one group pretest-posttest design. The results showed that the average number of children who experienced mental retardation before the puzzle game had unfavorable social adaptations and the average number of children who experienced mental retardation after doing the puzzle game had a fairly good social adaptation and there was no effect between playing technical skills. puzzle. For social adaptation of students with mental retardation in Dharma Wanita SDLB in the city of Bengkulu $(p=0.004)$. In conclusion, there is an influence between playing puzzle on the ability to adapt socially to mental retardation students at SDLB Dharma Wanita Bengkulu City.
\end{abstract}

Keywords: Social Adaptation, Puzzle Games, Mental Retardation 


\section{PENDAHULUAN}

Anak adalah amanah dan karunia Tuhan Yang Maha Esa, yang di dalam dirinya melekat harkat dan martabat sebagai manusia seutuhnya. Mereka bersih seperti kertas putih ketika awal dilahirkan ke dunia, belum mengerti untuk berbuat sesuatu kemudian orang tua yang mengajarkan dan memberi contoh untuk berbuat dan bertindak sebagaimana manusia. Anak mempunyai bakat, potensi dan sebagai generasi muda penerus cita-cita perjuangan bangsa, memiliki peran strategis dalam kehidupan masyarakat, berbangsa dan bernegara yang harus dijaga kesehatannya (Mutiah, 2013).

Kesehatan adalah hak asasi manusia, dan merupakan investasi sumber daya manusia yang paling mahal, serta memiliki kontribusi yang besar untuk meningkatkan Indek Pembangunan Manusia (Human Development Index-HDI). Oleh karena itu menjadi keharusan bagi semua pihak untuk memelihara, meningkatkan dan melindungi kesehatan demi kesejahteraan seluruh masyarakat. Upaya peningkatan tersebut dimulai dengan pemenuhan kebutuhan dasar manusia dengan perhatian utama pada proses tumbuh kembang anak sejak awal pertumbuhan sampai mencapai usia dewasa muda, termasuk juga kepada anak yang mengalami retardasi mental (Depkes RI, 2014).

Pada tahun 2002, American Association of Mental Retardation (AAMR) mengeluarkan definisi dari retardasi mental. AAMR adalah organisasi terbesar dan tertua yang fokus terhadap retadasi mental. Menurut AAMR, retardasi mental adalah disabilitas/ketidakmampuan yang ditandai dengan fungsi intelektual di bawah rata-rata dan rendahnya kemampuan untuk menyesuaikan diri (perilaku adaptif). Ketidakmampuan ini muncul sebelum berusia 18 tahun. Sekitar 2-3\% dari populasi dunia mengalami retardasi mental. Retardasi mental dapat muncul sebagai salah satu gejala dari gangguan atau penyakit lain. Retardasi mental merupakan keadaan anak dimana anak tersebut mengalami hambatan sehingga tidak dapat melalui perkembangan yang optimal. Retardasi mental bukan merupakan suatu penyakit, melainkan hasil patologik di dalam otak yang menggambarkan keterbatasan intelektualitas dan fungsi adaptif. Retardasi mental dapat terjadi dengan atau tanpa gangguan jiwa atau gangguan fisik lainnya (Salmiah, 2013).

Teori lainnya menyebutkan bahwa keterbelakangan mental (Retardasi Mental, RM) adalah suatu keadaan yang ditandai dengan fungsi kecerdasan umum yang berada dibawah rata-rata disertai dengan berkurangnya kemampuan untuk menyesuaikan diri (berperilaku adaptif), yang mulai timbul sebelum usia 18 tahun. Orang-orang yang secara mental mengalami keterbelakangan, memiliki perkembangan kecerdasan (intelektual) yang lebih rendah dan mengalami kesulitan dalam proses belajar serta adaptasi sosial. Tiga persen dari jumlah penduduk mengalami keterbelakangan mental (wardhani, 2012).

Retardasi mental merupakan masalah dunia dengan implikasi yang besar terutama bagi negara berkembang. World Health Organization (WHO) memperkirakan angka terjadinya retardasi mental berat sekitar 1-3\% pada dari seluruh populasi, dan hampir 3 $\%$ mempunyai IQ di bawah 70. Sebagai sumber daya manusia tentunya mereka tidak bisa dimanfaatkan, karena $0,1 \%$ dari anak-anak ini memerlukan perawatan, bimbingan serta pengawasan sepanjang hidupnya. Sedangkan di Indonesia jumlah anak berkebutuhan khusus adalah sekitar 7\% dari total jumlah anak usia 0-18 tahun atau sebesar 6.230.000. Insiden retardasi mental 1,5 kali lebih banyak pada laki-laki dibandingkan dengan perempuan, dimana kejadian tertinggi pada masa anak sekolah dengan puncak usia 6 sampai 17 tahun (Ramayumi, 2014). 
Seorang anak RM menunjukkan perkembangan yang secara signifikan lebih lambat dibandingkan dengan anak lain yang sebaya. Tingkat kecerdasan yang berada dibawah rata-rata bisa dikenali dan diukur melalui tes kecerdasan standar (tes IQ), yang menunjukkan hasil kurang dari 2 SD (standar deviasi) dibawah rata-rata (biasanya dengan angka kurang dari 70, dari rata-rata 100).

Menurut data di Dinas Kesejahteraan Sosial Propinsi Bengkulu tahun 2016, jumlah penyandang cacat dari usia 0-17 tahun adalah 1732 anak. Dengan penyandang cacat mental atau retardasi mental yaitu 553 anak atau $31.93 \%$.

Menurut data di SDLB Dharma Wanita Persatuan Provinsi Bengkulu, diketahui bahwa jumlah siswa SDLB pada tahun ajar 2013/2014 sebanyak 80 anak dengan jumlah anak yang menderita retardasi mental sebanyak 62 anak $(77,5 \%)$ dan pada tahun ajar 2015/2016 jumlah siswa SDLB sebanyak 78 anak dengan jumlah anak yang menderita retardasi mental sebanyak 62 anak $(79,4 \%$ ) (SDLB Dharma Wanita Persatuan Provinsi Bengkulu, 2016).

Pada anak dengan retardasi mental umumnya akan mengalami keterlambatan dalam fungsi kognitifnya yaitu IQ (Intelligence Quotient). Perkembangan pada anak dengan retardasi mental, biasanya tidak sesuai dengan usia mental anak normal seperti perkembangan motorik kasar, motorik halus, bahasa dan perkembangan sosial. Maka dari itu pada anak yang mengalami perlu mendapatkan perhatian yang serius dalam pembentukan sikap, kepribadian dan pengembangan kemampuan anak dalam beradaptasi sosial secara optimal (Mutiah, 2013).

Kemampuan beradaptasi sosial adalah salah satu syarat manusia untuk dapat bertahan hidup. Siswa SD memerlukan kemampuan ini dalam hubungan sosial sehingga ia mampu menyesuaikan dan menerima pembelajaran di sekolah. Secara umum adaptasi merupakan proses penyesuaian individu dengan lingkungan tempat ia hidup dan melaksanakan seluruh aktivitasnya sehari-hari (Wardhani, 2012).

Terdapat tiga jenis adaptasi, pertama adalah adaptasi morfologi yang merupakan penyesuaian bentuk tubuh untuk kelangsungan hidupnya, kedua disebut dengan adaptasi fisiologi merupakan penyesuaian fungsi fisiologi tubuh untuk mempertahankan hidupnya, dan ketiga adalah adaptasi tingkah laku merupakan adaptasi yang didasarkan pada tingkah laku. Dikaitkan dengan kemampuan siswa Sekolah Dasar, beradaptasi lebih ditekankan pada penyesuaian tingkah laku dalam hubungan sosial di sekolah. Siswa sebagai manusia biasa, mempunyai segala macam problema dalam hidupnya. Khususnya di lingkungan sekolah, siswa kurang atau belum mempunyai kemampuan dalam beradaptasi dengan lingkungan sosial. Padahal kemampuan beradaptasi ini mempunyai peranan penting untuk membentuk perilaku dan hubungan sosial siswa, terlebih lagi untuk mendukung tahap-tahap pendidikannya (Anwar, 2014).

Kemampuan beradaptasi pada masa kanak-kanak itu demikian pentingnya, sehingga jika anak tidak mencapai kemampuan beradaptasi minimum hingga sekitar usia enam tahun, besar kemungkinan mereka akan menghadapi masalah pada masa dewasanya. Kemampuan beradaptasi pada anak Sekolah Dasar terlihat dalam proses sosialisasi, anak menunjukkan perilaku sesuai aturan-aturan sosial yang ditentukan. Anakpun mulai membutuhkan teman dekat, yaitu teman sebagai orang yang dapat membantu jika dibutuhkan. Umumnya teman dekat ini adalah kelompok sebayanya (Mulyadi, 2011).

Kelompok sebaya dapat sebagai model dalam berperilaku, dimana anak cenderung meniru perilaku kelompoknya. Jika mempunyai teman berperilaku sesuai tuntutan masyarakat, anak pun akan mengikutinya. Berbagai karakteristik dari 
kelompok sebaya menunjukkan bahwa kelompok sebaya memiliki keunikan tersendiri yang mungkin tidak dijumpai di kelompok yan lain. Hal ini pula yang membuat anak sebagai anggota kelompok dapat mempelajari pola-pola perilaku anggota kelompoknya termasuk juga pada anak dengan retardasi mental (Hurlock, 2010).

Pada anak dengan retardasi mental memiliki kemampuan mudah latih (trainable) dan sulit didik (uneducable). Dengan demikian, proses pembelajarannya lebih berfokus pada kegiatan melatih anak dengan keterampilan yang memungkinkan mereka untuk dapat berfungsi pada lingkungan sosial. Program pelatihan khusus yang diberikan pada anak retardasi mental dilaksanakan sesuai dengan batas kemampuan anak. Terapi bermain merupakan pendekatan yang akan diujicobakan, hal tersebut dikarenakan anak retardasi mental pada umumnya akan mudah memahami suatu konsep atau kemampuan jika dalam situasi belajarnya menggunakan jenis materi yang konkret. Pelatihan yang diberikan bagi anak retardasi mental ini lebih ke arah permainan yang melatih bicara, keterampilan sederhana dalam lingkup aspek kognitif, psikomotorik, dan aspek sosial adaptif (Lisnawati, 2014).

Bermain adalah cara belajar yang efektif pada anak usia dini (Fauziddin, 2014), diantaranya bermain dengan memanfaatkan media. Salah satu media pembelajaran yang dapat digunakan yaitu puzzle. Secara umum media games puzzle akan memberikan manfaat baik bagi siswa, sebagaimana fungsi berbagai media diluar sekolah bagi para pelajar tentunya sebagai bahan tambahan pengetahuan yang tidak mereka dapat di sekolah. Oleh sebab itu guru harus memiliki pengetahuan dan pemahaman mengenai media yang cukup dan bervariasi. puzzle secara bahasa indonesia diartikan sebagai tebakan. Tebakan adalah sebuah masalah atau "enigma" yang diberikan sebagai hiburan; yang biasanya ditulis, atau dilakukan. Banyak tebakan berakar dari masalah matematika dan logistik serius lainnya, seperti masalah catur, diambil dari permainan papan. Lainnya lagi dibuat hanya sebagai pengetesan atau godaan otak (Marta, 2017).

Menurut Ismail (2011) puzzle adalah permainan yang menyusun suatu gambar atau benda yang telah di pecah dalam beberapa bagian. Cara memainkan Puzzle adalah memisahkan kepingan-kepingan yang dipisahkan lalu digabungkan kembali dan terbentuk menjadi sebuah gambar. Dengan memainkan puzzle anak usia dini dapat melatih kecerdasan inteligensi anak, sebab permainan ini anak benar- benar terpacu kemampuan berfikirnya untuk dapat menyatukan kembali posisi gambar pada tempatnya yang sesuai. Ada banyak jenis permainan puzzle salah satunya yaitu puzzle logika, dengan menggunakan puzzle logika guru dapat menstimulasi perkembangan kognitif anak dengan cara mengajak anak bermain puzzle. Dengan demikina naka mampu mengembangkan kemampuan kognitif yang berhubngan dengan posisi, warna dan arah, mampu menyusun puzzle dengan jumlah 7-12 kepingan secara acak, mampu menentukan letak kepingan puzzle secara benar dan sesuai, mampu menyelesaikan kepingan puzzle 5 menjadi bentuk utuh, mampu menyusun kepingan puzzle tiga tingkat dengan benar dan sesuai.

Melalui kegiatan bermain, anak akan belajar memberi dan menerima. Bermain dengan orang lain akan membantu anak untuk mengembangkan hubungan sosial dan belajar memecahkan masalah dari hubungan sosial dan belajar memecahkan masalah dari hubungan tersebut (Musfiroh, 2012).

Kenyataan di SDLB Dharma Wanita Kota Bengkulu tampak bahwa, siswa belum mampu bekerjasama, tidak memiliki rasa percaya diri, belum mampu mentaati peraturan dan disiplin sekolah. Secara keseluruhan perilaku yang tampak dari siswa tersebut adalah indikator dari kemampuan beradaptasi tingkah laku negatif dan apabila 
dipersentasekan kira-kira mencapai $40 \%$ dari 84 orang siswa di SDLB Dharma Wanita Kota Bengkulu. (SDLB Dharma Wanita Kota Bengkulu).

Sebagai upaya untuk mengatasi masalah siswa tersebut diatas maka perlu dicarikan strategi atau metode yang efektif untuk meningkatkan kemampuan beradaptasi dimaksud, salah satunya adalah metode bermain. Metode bermain yang termasuk dalam metode khusus konseling ini dipilih untuk mengarahkan dan melatih kemampuan siswa kaitannya dengan adaptasi tingkah laku dalam proses pembelajarannya di sekolah, dengan beberapa pertimbangan sebagai berikut: menurut Tedjasyaputra (2010) (1) Bermain peran lebih efektif dalam meningkatkan kemampuan beradaptasi, (2) Anak lebih menyukai metode bermain peran dibandingkan dengan model pembelajaran lainnya, (3) Bermain peran dapat menciptakan kemampuan adaptasi anak, maka perlu dilakukan penelitian tindakan secara cermat tentang kemampuan beradaptasi siswa disekolah.

Hasil studi awal yang dilakukan pada 40 anak dengan retardasi mental, didapatkan $76 \%$ mengalami hambatan dalam melakukan adaptasi sosial dengan lingkungan, mereka cenderung lebih asyik dengan kegiatannya sendiri, susah untuk melakukan sosialisasi, dan kaku pada lingkungan baru dan orang baru, bahkan dengan teman satu kelas sekalipun, yang mereka kenal. Tujuan dari penelitian ini adalah untuk mengetahui pengaruh bermain puzzle terhadap kemampuan beradaptasi sosial pada siswa Retardasi mental di SDLB Dharma Wanita Kota Bengkulu.

\section{METODE PENELITIAN}

Penelitian ini menggunakan desain penelitian pre exsperimental design dengan bentuk rancangan one group pretest-postest. Cara pengambilan sampel dalam penelitian ini adalah dengan menggunakan teknik purposive sampling yaitu teknik pengambilan sampel secara sengaja sesuai dengan persyaratan sampel yang diperlukan yaitu siswa kelas 3 dan 4 dijadikan sampel sehingga sampel berjumlah 12 orang. Instrumen yang digunakan dalam penelitian ini adalah lembar ceklist yang diisi peneliti dengan cara wawancara maupun observasi, sedangkan alat/bahan penelitian antaralain adalah alat permainan, seperti puzzel dan bola. Anak-anak diobservasi saat melakukan interaksi sosial melalui permainan puzzel, observasi ini dilakukan pada hari terakhir berinteraksi, aspek sosialisasi yang dinilai adalah interaksi saat bermain, fokus dalam kegiatan bermain,kontak mata, kooperatif anak saat bermain, sampai dengan kemampuan anak saat berkomunikasi, puzzel yang dimainkan adalah menyusun karakter binatang, yang dilakukan pada 6 pasang anak dengan retardasi mental. Observasi dilakukan selama 6 hari, dengan pasangan yang berbeda setiap harinya. Analisis data ini dilakukan dengan uji statistik wilcoxon signed rank test dan mann whitney $u$ test dengan tingkat kemaknaan $\alpha=0,05$. 


\section{HASIL PENELITIAN}

\section{Analisis Unvariat}

Tabel. 1

Rata-Rata Adaptasi Sosial Anak dengan Retardasi Mental

Sebelum dan Sesudah Melakukan Permainan Puzzle

\begin{tabular}{clccccc}
\hline No & \multicolumn{2}{c}{ Variabel } & N & Mean & Max & Min \\
\hline 1 & $\begin{array}{l}\text { Adaptasi sosial anak dengan retardasi } \\
\text { mental sebelum melakukan permainan } \\
\text { puzzle }\end{array}$ & 30 & 4,9 & 7 & 3 \\
\hline $\begin{array}{l}\text { Adaptasi sosial anak dengan retardasi } \\
\text { mental sesudah melakukan permainan } \\
\text { puzzle }\end{array}$ & 30 & 6,67 & 9 & 4 \\
\hline
\end{tabular}

Berdasarkan tabel 1 diatas menunjukan bahwa rata-rata anak yang mengalami retardasi mental sebelum dilakukan permainan puzzle mempunyai adaptasi sosial yang kurang baik dan rata-rata anak yang mengalami retardasi mental sesudah dilakukan permainan puzzle mempunyai adaptasi sosial yang cukup baik.

\section{Analisis Bivariat}

\section{Tabel. 2}

Pengaruh Bermain Puzzle terhadap Kemampuan Beradaptasi Sosial pada Siswa Retardasi Mental

\begin{tabular}{|c|c|c|c|c|c|c|}
\hline Variabel & Mean & Std. Dev & Std. Error Mean & $\mathrm{T}$ & df & $\mathrm{P}$ value \\
\hline $\begin{array}{l}\text { Kemampuan Beradaptasi } \\
\text { Sosial Pada Siswa Retardasi } \\
\text { mental sebelum dan sesudah } \\
\text { dilakukan permainan Puzzle }\end{array}$ & 1.75 & 1.6583 & 0.4787 & -3.656 & 11 & 0.004 \\
\hline
\end{tabular}

Berdasarkan tabel 2 diatas dapat diketahui rata-rata peningkatan skor adaptasi sosial pada anak yang mengalami retardasi sosial sebesar 1,75. Hasil analisis uji $t$ didapatkan nilai $\mathrm{p}=0,004$ lebih kecil dari pada nilai alpha 0,05 artinya ada pengaruh antara bermain puzzle terhadap kemampuan beradaptasi sosial pada siswa retardasi mental di SDLB Dharma Wanita Kota Bengkulu. 


\section{PEMBAHASAN}

\section{Gambaran Kemampuan Beradaptasi Sosial pada Siswa Retardasi Mental Sebelum Dilakukan Intervensi Terapi Bermain Puzzle}

Hasil penelitian ini menunjukkan menunjukan bahwa rata-rata anak yang mengalami retardasi mental sebelum dilakukan permainan puzzle mempunyai adaptasi sosial yang kurang baik. Berdasarkan hasil penelitian ini dapat dijelaskan bahwa ratarata anak yang mengalami retardasi mental mempunyai adaptasi sosial yang kurang baik dengan mean 4,9.

Adaptasi sosial adalah dapat diartikan sebagai proses belajar individu untuk mengenal dan menghayati norma-norma serta nilai-nilai sosial sehingga terjadi pembentukan sikap untuk berperilaku sesuai dengan tuntutan atau perilaku masyarakatnya. Menurut Nani (2010) bahwa perkembangan sosial anak retardasi mental sangat tergantung pada bagaimana perlakuan dan penerimaan lingkungan terutama lingkungan keluarga terhadap anak. Perkembangan sosial anak akan tumbuh dengan baik apabila sejak awal dalam interaksi bersama keluarga tumbuh elemen-elemen saling membantu, saling menghargai, saling mempercayai dan saling toleransi.

Gangguan adaptasi soslal pada anak RM dapat disebabkan karena anak yang mengalami retardasi mental fungsi intelektual di bawah rata-rata sehingga sulit untuk melakukan kegiatan yang sesuai dengan anak yang normal. Namun setelah dilakukan permainan puzzle secara berkelompok kepada anak yang mengalami retardasi mental kemampuan anak dalam beradaptasi sosial mengalami peningkatan. Walaupun masih ada beberapa responden yang tidak mengalami perubahan dalam adaptasi sosialnya, hal ini dapat terjadi karena stimulasi permainan yang diberikan hanya sekali sehingga respon yang terlalu jauh bagi anak dalam beradaptasi dengan temannya selain itu juga keadaan ini dapat disebabkan karena karakteristik anak yang mengalami retardasi mental berbeda-beda juga dapat mempengaruhi kemampuan anak dalam beradaptasi sosial.

Menurut Videback (2010) retardasi mental merupakan gangguan fungsi intelektual di bawah rata-rata (IQ di bawah 70) yang disertai dengan keterbatasan yang penting dalam area fungsi adaptif, seperti keterampilan interpersonal atau sosial, penggunaan sumber masyarakat, penunjukkan diri, keterampilan akademis, pekerjaan, waktu senggang, dan kesehatan serta keamanan. Adaptasi sosial merupakan salah satu bentuk penyesuaian diri dalam lingkungan sosial. Penyesuaian ini dapat berarti mengubah diri pribadi sesuai dengan keadaan lingkungan, jadi dapat berarti mengubah lingkungan sesuai dengan keadaan pribadi. Adaptasi itu sendiri pada hakekatnya adalah suatu proses untuk memenuhi syarat-syarat dasar untuk tetap melangsungkan kehidupan (Gerungan, 2009).

Kemampuan beradaptasi pada masa kanak-kanak itu demikian pentingnya, sehingga jika anak tidak mencapai kemampuan beradaptasi minimum hingga sekitar usia enam tahun, besar kemungkinan mereka akan menghadapi masalah pada masa dewasanya. Kemampuan beradaptasi pada anak Sekolah Dasar terlihat dalam proses sosialisasi, anak menunjukkan perilaku sesuai aturan-aturan sosial yang ditentukan. Anakpun mulai membutuhkan teman dekat, yaitu teman sebagai orang yang dapat membantu jika dibutuhkan. Umumnya teman dekat ini adalah kelompok sebayanya (Mulyadi, 2011).

Menurut Hurlock (2010), peran aktif anak dalam bermain dengan teman sebayanya dapat berpengaruh terhadap kemampuan anak dalam beradaptasi sosial. Anak harus memacu dirinya sendiri untuk berinteraksi dengan lingkungan sekitarnya. 
Dengan adanya teman dalam satu kelompok anak bisa saling berdiskusi dan bekerja sama dengan teman sekelompok, serta dengan adanya kelompok lawan yang memiliki tingkat kemampuan sosialisasi yang berbeda dapat memotivasi anak untuk tertarik dan beradaptasi dengan permainan. Saat melihat kelompok lawan yang lebih interaktif dan mampu menyusun kepingan puzzle dengan tepat sehingga mendapatkan pujian dari terapis, maka anak akan termotivasi untuk dapat bermain seperti kelompok lawan mainnya.

Menurut H. Bonner dalam bukunya social psycholog menyebutkan bahwa salah satu bentuk adaptasi social adalah, interaksi sosisal merupakan suatu hubungan antara dua atau lebih individu manusia, dimana perilaku individu yang satu mempengaruhi, mengubah atau memperbaiki kelakuan individu yang lainnya atau sebaliknya (Mubarak, 2009). Interaksi sosial adalah hubungan antar sesama manusia dalam suatu lingkungan masyarakat yang menciptakan satu keterikatan kepentingan yang menciptakan status social (Mubarak, 2009). Juga dapat diartikan sebagai hubungan sosial dinamis yang menyangkut hubungan orang perorangan antar kelompok-kelompok manusia maupun antara orang-orang perorangan dengan kelompok manusia. Pada anak retardasi mental sulit melakukan interaksi sosial dengan baik dengan masyarakat dan tetap bergantung pada keluarga hal ini dikarenakan hambatan secara fisiologis anak yang berbeda dengan anak normal. Lingkungan keluarga membantu interaksi sosial anak dengan bertemu, berbicara dan berkomunikasi. Keluarga sebagai tempat interaksi pertama kali sebelum kemasyarakat. Interaksi sosial dengan keluarga akan membantu anak untuk berinteraksi dengan mayarakat nantinya. Jadi, anak belajar interaksi sosial dari anggota keluarga, disini keluarga mempengaruhi, mengubah atau memperbaiki perilaku anak untuk kehidupan dewasa nantinya. Pada anak retardasi mental akan belajar berinteraksi sosial dari keluarga dan sekolah, di sekolah anak belajar berinteraksi sosial dengan guru dan teman sebayanya. Interaksi sosial tersebut berupa bermain bersama teman sebaya dan bekerja sama dengan kelompok bermain.

Dari hasil Jurnal Keperawatan Kurniawan (2013) di SDLB Negeri Sukoharjo Pati Jawa Tengah menunjukkan bahwa kemampuan sosialisasi anak retardasi mental dalam kriteria baik 13 (50\%) dan kemampuan sosialisasi anak retardasi mental dalam kriteria kurang baik 13 (50\%). Hasil penelitian Rahmanto (2012) di SDLB Negeri Sukoharjo Pati Jawa Tengah penelitian kemampuan sosialisasi anak retardasi mental di SDLB Negeri Sukoharjo Pati rata-rata adalah kurang.

\section{Gambaran Kemampuan Beradaptasi Sosial pada Siswa Retardasi Mental Sesudah Dilakukan Intervensi Bermain Puzzle}

Rata-rata anak yang mengalami retardasi mental sesudah dilakukan permainan puzzle mempunyai adaptasi sosial yang cukup baik dapat dilihat dari peningkatan mean yang sebelum intervensi 4,9 mengalami peningkatan menjadi 6.67, Nilai kemampuan sosialisasi pada anak RM setelah diberikan terapi bermain: cooperative play dengan puzzle dapat dilihat pada kelompok perlakuan mengalami peningkatan hampir di semua kemampuan sosialisasi, sedangkan pada kelompok kontrol hanya sebagian item saja yang mengalami peningkatan, meliputi kemampuan sosialisasi point ke-1 (kontak mata), point ke-5 (bermain dengan teman sebaya), point ke-7 (tetap bermain dengan teman walaupun tidak ada guru/pengasuh disaat jam istirahat), point ke- 8 (berpartisipasi aktif dalam kegiatan), dan point ke-10 ( bekerja sama dalam kegiatan).

Sosialisasi adalah proses perkembangan sosial dalam memperoleh kemampuan berfikir yang sesuai dengan tuntunan sosial. Perkembangan sosial merupakan 
pencapaian kematangan dalam bersosialisasi, dan dapat juga sebagai bentuk proses belajar untuk menyesuaikan diri terhadap norma-norma kelompok, moral, tradisi, dan menjadi satu kesatuan dan saling berkomunikasi serta bekerjasama. Sosialisasi ini mengajari kita secara terus-menurus sepanjang kehidupan kita didalam masyarakat. Secara dominan sosialisasi dilakukan dengan sengaja, tetapi sosialisasi juga terjadi tanpa disadari ketika individu mengambil petunjuk mengenai norma-norma sosial tanpa pengajaran khusus mengenai hal itu. Sosialisasi sangat penting artinya dalam mempersiapkan setiap individu anggota masyarakat agar dapat memahami perananperanan orang lain dan peranan dirinya bagi orang lain dalam kehidupan masyarakat (Sutarya, 2005).

Menurut asumsi peneliti, anak retardasi mental memiliki hambatan dalam kemampuan berfikir terkadang disertai dengan kelainan fisik. Sehingga anak retardasi mental membutuhkan bantuan dari orang-orang terdekatnya untuk dapat menumbuhkan rasa percaya diri untuk berinteraksi dan bersosialisasi dengan lingkungan sekitarnya maupun dengan teman-tamannya. Kemampuan sosialisasi anak retardasi mental tidak hanya didapatkannya dalam lingkungan sekolah tetapi dalam lingkungan keluarga juga dapat mempengaruhi kemampuan sosialisasi anak. Dalam lingkungan keluarga, orang tua perlu lebih banyak menggali informasi bagaimana dan sejauh mana anak memiliki kemampuan sosialisasi.

Kemampuan sosialisasi anak juga didapat dari lingkungan sekolah seperti guru dan teman sebaya. Hal diatas selaras dengan teori yang dikemukakan oleh Herman (2008) yaitu faktor-faktor yang mempengaruhi kemampuan sosialisasi diantaranya adalah keluarga. Bagi keluarga inti (nuclear family) agen sosialisasi meliputi ayah, ibu, saudara kandung, dan saudara angkat yang belum menikah dan tinggal secara bersamasama dalam satu rumah. Sedangkan pada masyarakat yang menganut sistem kekerabatan diperluas (extended family), agen sosialisasinya menjadi lebih luas karena dalam satu rumah dapat saja terdiri atas beberapa keluarga yang meliputi kakek, nenek, paman, dan bibi disamping anggota keluarga inti. Selain keluarga, teman pergaulan juga merupakan faktor yang mempengaruhi sosialisasi. Pada awalnya, teman bermain dimaksudkan sebagai kelompok yang bersifat rekreatif, namun dapat pula memberikan pengaruh dalam proses sosialisasi setelah keluarga. Kelompok bermain lebih banyak berperan dalam membentuk kepribadian seorang individu. Lembaga pendidikan formal (sekolah) juga salah satu faktor yang mempengaruhi kemampuan sosialisasi anak. Sekolah luar biasa sebagai tempat pendidikan formal bagi anak cacat yaitu penderita tunanetra, tunarungu, tunagrahita, penyandang cacat tubuh dan tunalaras. Adapun SLB diselenggarakan di Taman KanakKanak Luar Biasa (TKLB), Sekolah Dasar Luar Biasa (SDLB), Sekolah Lanjutan Tingkat Pertama Luar Biasa (SLTPLB) dan Sekolah Menengah Luar Biasa (SMLB).

Anak RM memerlukan stimulasi yang lebih dibandingkan anak normal untuk mengembangkan kemampuan sosialisasinya. Meskipun anak sudah mendapatkan pendidikan di sekolah khusus, tetapi kemampuan sosialisasinya masih kurang. Hal ini dikarenakan materi di sekolah lebih difokuskan untuk peningkatan inteligent. Kegiatan yang dilakukan secara bersama / berkelompok masih jarang dilakukan, seperti bermain secara berkelompok, sehingga peran aktif anak untuk memacu dirinya untuk berinteraksi dengan lingkungan sekitar juga kurang. Untuk itu diperlukan stimulasi berupa kegiatan / permainan yang dapat dilakukan dengan berkelompok secara rutin dan berkelanjutan demi meningkatkan peran aktif anak dalam mengembangkan kemampuan sosialisasinya. 
Pendidikan orang tua juga mempengaruhi perkembangan kemampuan sosialisasi anak RM. Karena sebagian besar pendidikan orang tua responden SMA/Sederajat ke bawah, hal ini berdampak pada minimnya pengetahuan yang diperoleh seputar kondisi anak dan pemenuhan kebutuhan/stimulasi untuk mengembangkan kemampuan sosialisasinya. Kemampuan sosialisasi anak dipengaruhi oleh pendidikan anak, peran aktif anak, pendidikan orang tua, peran aktif orang tua, dan lingkungan. Setiap anak mampu mempunyai kemampuan sosialisasi yang optimal bila mendapat stimulasi yang tepat. Disetiap fase pertumbuhan, anak membutuhkan rangsangan untuk mengembangkan kemampuan mental dan sosialisasinya. Anak setelah diberi stimulasi mampu melakukan tahapan perkembangan yang optimal (Wardhani, 2012).

Pendidikan untuk anak RM dapat berupa sekolah khusus maupun tempat terapi. Pendidikan anak juga dapat mempengaruhi kemampuan sosialisasinya, karena ditempat ini mengharuskan mereka untuk dapat berkomunikasi dan berinteraksi dengan baik. Anak yang mampu belajar dengan baik akan memiliki pengetahuan dan informasi sehingga mampu beradaptasi dengan baik. Peran aktif anak juga dapat berpengaruh. Anak harus memacu dirinya sendiri untuk berinteraksi dengan lingkungan sekitarnya. Dengan adanya teman dalam satu kelompok anak bisa saling berdiskusi dan bekerja sama dengan teman sekelompok, serta dengan adanya kelompok lawan yang memiliki tingkat kemampuan sosialisasi yang berbeda dapat memotivasi anak untuk tertarik dan beradaptasi dengan permainan. Saat melihat kelompok lawan yang lebih interaktif dan mampu menyusun kepingan puzzle dengan tepat sehingga mendapatkan pujian dari terapis, maka anak akan termotivasi untuk dapat bermain seperti kelompok lawan mainnya (Lisnawati, 2014).

Menurut Hurlock (2010) selain dalam diri anak, keluarga merupakan faktor terpenting yang mempengaruhi interaksi sosial anak, karena hubungan keluarga lebih erat dan lebih emosional. Peran aktif orang tua sangat dibutuhkan untuk membimbing dan mengawasi anak. Orang tua dapat memberi stimulus berupa kasih sayang sehingga anak merasa diperhatikan dan lebih terbuka untuk berkomunikasi, karena anak akan cenderung mengungkapkan keinginannya kepada orang terdekat yang meraka percayai, dalam hal ini orang tua.

Berdasarkan data demografi orang tua responden didapatkan bahwa ayah dan ibu responden sebagian besar berpendidikan SMA/sederajat ke bawah. Tingkat pendidikan orangtua responden yang rendah berdampak pada minimnya pengetahuan yang diperoleh sehingga mempengaruhi kondisi anak dalam mendapatkan pemenuhan kebutuhan dan stimulasi untuk mengembangkan kemampuan sosialisasi. Semakin tinggi tingkat pendidikan orang tua diharapkan semakin cepat pemahaman orang tua terhadap kondisi anak mereka, sehingga orang tua dapat mengerti hal-hal seputar kondisi anaknya. Sebagian besar ayah responden baik kelompok perlakuan maupun kelompok kontrol bekerja sebagai pegawai swasta, sedangkan ibu responden sebagian besar adalah ibu rumah tangga, sehingga sebagian besar waktunya dapat diberikan untuk anak. Mereka dapat secara langsung melakukan banyak hal untuk anaknya tanpa melalui orang lain, baik itu anggota keluarga yang lain ataupun pengasuh anak. Hal ini akan membuat anak merasa mendapatkan dukungan penuh dari orang tuanya (Mulyadi, 2011).

Orang tua responden pada kelompok perlakuan maupun pada kelompok kontrol sebagian besar memiliki 2 orang anak, sehingga perhatian, kasih sayang, dan waktu untuk bersama dengan anak lebih banyak. Orang tua dapat bermain dan berkomunikasi dengan anak secara lebih intens. Hal ini akan membantu anak dengan lebih mudah 
untuk meningkatkan kemampuan komunikasi, karena sebagaian besar waktu anak dihabiskan bersama keluarganya (Salmiah, 2013).

Lingkungan di sekitar anak RM juga mempengaruhi kemampuan sosialisasinya. Lingkungan yang kondusif dan dapat menerima keterbatasan anak akan mempermudah anak untuk mengekspresikan diri dalam berinteraksi dengan orang lain. Di sekolah khusus, kebutuhan anak RM memang lebih terpenuhi karena lingkungan fisik, pengajar maupun kurikulumnya sudah dirancang sedemikian rupa sehingga lebih cocok dengan kondisi anak. Hal ini dapat meningkatkan kepercayaan diri anak. Anak tidak merasa aneh terhadap dirinya sendiri atau tertinggal dari teman lain yang normal. Akan tetapi di sekolah lebih difokuskan untuk peningkatan intelligen daripada kemampuan yang lain seperti kemampuan sosialisasi, sehingga meskipun anak telah bersekolah lebih dari 2 tahun, masih ditemui anak yang memiliki kemampuan sosialisasi kurang. Di lingkungan keluarga dan masyarakat yang memandang wajar terhadap anak RM akan menciptakan lingkungan yang baik untuk perkembangannya.

\section{Pengaruh Bermain Puzzle terhadap Kemampuan Beradaptasi Sosial pada Siswa Retardasi Mental}

Hasil penelitian ini menunjukkan bahwa rata-rata peningkatan skor adaptasi sosial pada anak yang mengalami retardasi sosial sebesar 1,75. Hasil analisis uji t didapatkan nilai $\mathrm{p}=0,004$ lebih kecil dari pada nilai alpha 0,05 artinya ada pengaruh antara bermain puzzle terhadap kemampuan beradaptasi sosial pada siswa retardasi mental di SDLB Dharma Wanita Kota Bengkulu.

Hasil penelitian ini sesuai dengan yang dikemukakan oleh Hidayat (2012) yang mengatakan bahwa permainan adalah alat stimulasi pertumbuhan dan perkembangan anak. Perkembangan sosial ditandai dengan kemampuan berinteraksi dengan lingkungannya. Melalui kegiatan bermain, anak akan belajar memberi dan menerima. Bermain dengan orang lain akan membantu anak untuk mengembangkan hubungan sosial dan belajar memecahkan masalah dari hubungan sosial dan belajar memecahkan masalah dari hubungan tersebut.

Hasil penelitian ini sesuai juga dengan teori Hurlock (2010) salah satu cara anak bergaul dengan temannya adalah melalui permainan. Kegiatan bermain mempunyai sumbangan positif terhadap penyesuaian sosial maupun penyesuaian diri anak dan perkembangan emosi, kepribadian maupun perkembangan kognisi. Melalui kegiatan bermain inilah anak mendapat pengalaman dengan temannya. Pengalaman yang diperoleh anak ini membantunya dalam melakukan penyesuaian sosial dengan teman sebayanya.

Menurut Somantri (2007) yang mengatakan bahwa perkembangan keterampilan emosional dan sosial pada anak retardasi mental ringan dan sedang dapat dioptimalkan dengan menggunakan metode terapi bermain. Terapi bermain yang digunakan adalah yang melibatkan interaksi dengan orang lain. Bermain merupakan bagian integral dari masa anak-anak, suatu media unik sebagai sarana mengembangkan keterampilan bahasa ekspresif, keterampilan komunikasi, perkembangan emosional, keterampilan sosial, kemampuan membuat keputusan dan perkembangan kognisi pada anak. Pada saat melakukan aktifitas bermain, anak belajar berinteraksi dengan teman, memahami bahasa lawan bicara, dan belajar tentang nilai sosial yang ada pada kelompoknya.

Hasil penelitian ini sesuai dengan Hasil penelitian Wardhani (2012) di SLB AlHidayah desa Mejayan Kabupaten Madiun menunjukkan bahwa hasil uji Mann Whitney $U$ Test didapatkan nilai $\mathrm{p}=0,036$ dimana $\mathrm{p} \leq 0,05$, maka terdapat perbedaan yang 
signifikan antara kelompok perlakuan dan kelompok kontrol, yang berarti ada pengaruh terapi bermain: cooperative play dengan puzzle terhadap peningkatan kemampuan sosialisasi pada anak retardasi mental di SLB Al-Hidayah desa Mejayan Kabupaten Madiun.

Berdasarkan hasil penelitian dan beberapa teori yang telah dikemukakan dapat disimpulkan bahwa permainan puzzle dapat meningkatkan adaptasi sosial anak dimana dengan permainan puzzle secara kelopok anak akan belajar berkomunikasi dengan baik dengan temannya dalam memecahkan teka-teki dalam permainan puzzle selain itu juga dengan permainan puzzle ini anak dituntut untuk berfikir lebih aktif sehingga dapat memancing respon dan daya fikir anak, dengan terjalinnya komunikasi yang baik dari anak satu dan lainya akan meningkatkan hubungan sosial anak yang baik dengan teman satu kelompoknya.

Agar hasil maksimal, terapi bermain: cooperative play dengan puzzle dilakukan melalui kelompok-kelompok kecil dengan tujuan agar siswa retardasi mental lebih berkonsentrasi dalam penyusunan puzzle dan terapis lebih berkonsentrasi dalam melihat interaksi yang dilakukan siswa, sehingga dapat memberikan koreksi langsung, maupun stimulasi serta dapat melihat dan menilai perkembangan siswa. Dengan kecerdasan anak RM yang dibawah normal, maka anak RM membutuhkan latihan yang sering dan berkelanjutan agar anak tidak cepat lupa dengan teknik permainan yang diajarkan. Pada pertemuan selanjutnya sebagian besar responden sudah bisa mengikuti permainan sesuai peraturan. Setelah dilakukan terapi bermain: cooperative play dengan puzzle, responden sudah mampu berkomunikasi dan bekerja sama dalam menyusun puzzle.

Kemampuan sosialisasi berkembang berdasarkan waktu, pengalaman/latihan, dan pengetahuan (Hutomi, 2011). Diharapkan kegiatan terapi bermain: cooperative play dengan puzzle dapat diaplikasikan oleh perawat, orang tua, serta guru sebagai salah satu metode untuk melatih dan meningkatkan kemampuan sosialisasi pada anak retardasi mental.

Setelah dilakukan terapi bermain: cooperative play dengan puzzle, pada kelompok perlakuan terjadi peningkatan kemampuan sosialisasi pada anak RM. Hal ini dikarenakan pada kelompok perlakuan mendapatkan stimulasi secara rutin dan berkelanjutan, sehingga menstimulasi anak untuk berperan aktif dalam kegiatan, yang dapat meningkatkan kemampuan sosialisasinya. Terapi bermain: cooperative play dengan puzzle dapat meningkatkan kemampuan sosialisasi pada anak RM. 


\section{SIMPULAN}

Berdasarkan hasil penelitian mengenai pengaruh antara bermain puzzle terhadap kemampuan beradaptasi sosial pada siswa retardasi mental di SDLB Dharma Wanita Kota Bengkulu dapat ditarik kesimpulan sebagai berikut: Rata-rata anak yang mengalami retardasi mental sebelum dilakukan permainan puzzle mempunyai adaptasi sosial yang kurang baik dan rata-rata anak yang mengalami retardasi mental sesudah dilakukan permainan puzzle mempunyai adaptasi sosial yang cukup baik. Ada pengaruh antara bermain puzzle terhadap kemampuan beradaptasi sosial pada siswa retardasi mental di SDLB Dharma Wanita Kota Bengkulu.

\section{SARAN}

Kepada intansi kesehtan diharapkan dapat melakukan upaya meningkatkan kesehatan anak dengan retardasi mental dengan melakukan terapi-terapi kelompok pada anak dengan retardasi mental secara berkala dengan tenaga-tenaga kesehatan yang terlatih dibidangnya sehingga masalah social anak dengan retardasi mental dapat diminimalkan. Dan kepada pihak sekolah untuk memberikan suatu materi tambahan tentang adaptasi social pada anak melalui berbagai permainan yang anak minati, hal ini secara berlahan akan menimbulkan kepercayaan diri anak secara berangsur. 


\section{DAFTAR PUSTAKA}

Behrman. (2000). Ilmu Kesehatan Anak Nelson Vol. I. Jakarta: EGC

Depkes RI. (2014). Pedoman Pelayanan Kesehatan Anak di Sekolah Luar Biasa (SLB) Bagi Petugas Kesehatan. Departemen Kesehatan RI: Jakarta

Fauziddin, M. (2014). Pembelajaran PAUD Bermain, Cerita dan Menyanyi Secara Islami. Bandung: PT. Remaja Rosdakarya

Gerungan. (2009). Psikologi Sosial. PT Refika Asitama: Bandung

Gunarsa. (2004). Bunga Rampai Psikologi Perkembangan. dari Anak sampai Usia Lanjut. Jakarta: SBPK Gunung Mulia

Gunawan. (2010). Sosiologi Pendidikan. Jakarta: Rineka Cipta

Herman, M. (2008). Sosialisasi pada Tahap Perkembangan Anak. Jakarta: PT Setya Karya

Hidayat. (2011). Metode Penelitian Kebidanan Teknik Analisa Data. Salemba Medika: Jakarta

Hurlock. (2012). Perkembangan Anak. Edisi 4. Erlangga: Jakarta

Hutomi, L. (2011). Sosialisasi - Sebuah Pengantar Sosiologi, Media Release 9 Juni, diakses hari Senin 24 Maret 2016 pukul 20.00 WIB, uthfihutomi.blogspot.com/./sosialisasi-sebuah-pengantar-sosiologi

Ismail, A. (2011). Education Games. Jogjakarta: Pro U Media

Kurniawan. (2013). Hubungan antara Dukungan Keluarga dengan Kemampuan Sosiaisasi Anak Retardasi Mental Kelas 1 di SDLB Negeri Sukoharjo Pati. Skripsi. STIKES Ngudi Waluyo Ungaran

Lisnawati. (2014). Analisis Keberhasilan Terapi Bermain terhadap Perkembangan Potensi Kecerdasan Anak Retardasi Mental Sedang Usia 7-12 Tahun. Sekolah Tinggi Ilmu Kesehatan Respati Tasikmalaya. MKB, 46(2). Juni 2014

Marta, R. (2017). Penanganan Kognitif Down Syndrome melalui Metode Puzzle pada Anak Usia Dini. Jurnal Obsesi: Jurnal Pendidikan Anak Usia Dini, 1(1), 32-41. doi: 10.31004/obsesi.v1i1.29

Mubarak, Wahit Iqbal. (2009). Sosiologi untuk Keperawatan. Jakarta: Salemba Medika Mulyadi. (2011). Mengembangkan Kreativitas Anak melalui Bermain. UMS: Surakarta

Musfiroh. (2012). Cerdas Melalui Bermain. PT Grasindo: Jakarta

Mutiah. (2010). Psikologi Bermain Anak Usia Dini. Kencana: Jakarta

Nani, D. (2010). Pengaruh Dukungan Sosial terhadap Kemampuan Sosialisasi Anak Berkebutuhan Khusus. Universitas Jendral Soedirman. Skrispsi

Notoatmodjo. (2010). Metodologi Penelitian Kesehatan. PT Rineka Cipta: Jakarta

Rahmanto. (2011). Hubungan antara Kemampuan Berbahasa dengan Kemampuan Sosialisasi Anak Retardasi Mental Sedang di Slb Negeri Sukoharjo. Skripsi. Universitas Muhammadiyah Surakarta

Rakhmawati, I. (2008). Pengaruh Aktivitas Bermain Sosial: Cooperative Play terhadap Interaksi Sosial Anak dengan Gejala Kepibadian Introvert, Skripsi. PSIK FK UNAIR

Ramayumi. (2014). Karakteristik Penderita Retardasi Mental di SLB Kota Bukittinggi. Artikel Penelitian. MKA, 37(3). Desember 2014

Salmiah, S. (2013). Retardasi Mental. Fakultas Kedokteran Gigi Universitas Sumatera Utara

Santoso. (2010). Teori-Teori Psikologi Sosial. PT Refika Aditama: Bandung

Schwartz. (2005). Pedoman Klinis Pediatri. Jakarta: EGC 
SDLB Dharma Wanita Persatuan Provinsi Bengkulu. (2015). Data Siswa Tingkat SDLB Dharma Wanita Persatuan Provinsi Bengkulu

Setiadi. (2007). Ilmu Sosial Dan Budaya Dasar. Kencana Prenada Media Group: Jakarta Sibagariang. (2010). Buku Saku Metodologi Penelitian Untuk Mahasiswa Diploma Kesehatan. Trans Info Media: Jakarta

Simatupang. (2005). Bermain Sebagai Upaya Dini Menanamkam Aspek Sosial bagi Siswa Sekolah Dasar. Jurnal Pendidikan Jasmani Indonesia, 3(1), 2005

Soekanto. (2012). Sosiologi Suatu Pengantar. PT Raja Grafindo Persada: Jakarta

Soetjiningsih. (2010). Perkembangan Anak dan Permasalahannya. Sagung Seto: Jakarta

Somantri. (2007). Psikologi Anak Luar Biasa. Refika Aditama. Bandung. Hal.103-105

Somantri. (2007). Psikologi Anak Luar Biasa. Refika Aditama: Bandung

Sunaryo. (2004). Psikologi untuk Keperawatan. Jakarta: EGC

Supartini. Y. (2004). Konsep Dasar Keperawatan Anak. EGC: Jakarta

Sutarya. (2005). Sekolah, Sosialisasi Anak dan Keluarga. Jakarta: Garisindo

Videback. (2010). Buku Ajar Keperawatan Jiwa. Jakarta: EGC

Wardhani. (2012). Terapi Bermain: Cooperative Play dengan Puzzle Meningkatkan Kemampuan Sosialisasi Anak Retardasi Mental di SLB Al - Hidayah, desa Mejayan, Kabupaten Madiun. Skripsi. Fakultas Keperawatan Universitas Airlangga Kampus C Mulyorejo Surabaya

Wong. (2009). Buku Ajar Keperawatan Pediatrik. Vol. 1. Edisi 6. EGC: Jakarta 